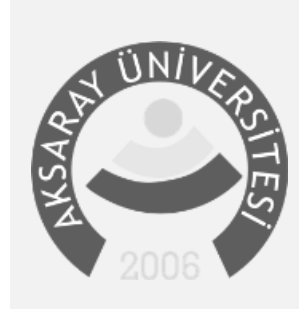

AKSARAY ÜNIVERSİTESI

İKTISSADİ VE IDDARİ BILIMLER FAKÜLTESİ DERGISSI

JOURNAL OF AKSARAY UNIVERSITY FACULTY OF ECONOMICS

AND ADMINISTRATIVE SCIENCES

dergipark.gov.tr/aksarayiibd

Araștırma Makalesi • Research Article

\title{
Kayıt Dışı Ekonomiye Karşı Halkın Bilinçlendirilmesi Bağlamında Alınması Gereken Önlemler
}

\author{
The Measures Which Are To Be Taken Against Informel Economy Within The Context Of \\ Awareness Of People's
}

\section{Hasan Dursun ${ }^{l}$ ve Adem Dă̆c $\iota^{2}$}

${ }^{1}$ Dr.Öğr. Üyesi, Özyeğin Üniversitesi, Hukuk Fakültesi, hasan.dursun@ozyegin.edu.tr, Orcid ID:0000-0002-5506-3944

${ }^{2} \ddot{O} \breve{g r}$. Gör., Niğde Ömer Halisdemir Üniversitesi, Niğde Sosyal Bilimler MYO, adagci@ohu.edu.tr, Orcid ID: 0000-0003-0655-9625

MA K A L E B İ L G İ S I

\section{Anahtar Kelimeler}

Kayıt Dişı Ekonomi,

Enformel Ekonomi,

Gölge Ekonomi,

Kayıt Dışı Ekonominin Zararları,

Toplumsal Bilinç.

Makale Geçmişi:

Geliş Tarihi:1 Mart 2021

Kabul Tarihi:14 Mayıs 2021

A R T I C LE IN F O

\section{Keywords}

Underground Economy,

Informal Economy,

Shadow Economys,

Damages of Underground

Economy,

Public Conscious

\section{Article History:}

Received: 1 March 2021

Accepted: 14 May 2021
Ö Z E T

Farklı kavramlarla ifade edilen kayıt dışı ekonomi Türkiye'nin karşı karşıya kaldığı en önemli sorunlardan birisini oluşturmaktadır. Kayıt dışı ekonominin verdiği zararlar sayılamayacak kadar çok olsa da en önemlilerini şu şekilde saymak olanaklıdır: Kayıt dışı ekonomi, AB’ye tam üyelik yolunda engel oluşturmakta, GSYH hesaplarını bozarak ve vergi gelirlerini azaltarak kalkınmanın sağlanmasını olanaksız veya oldukça güç hale getirmektedir. Yine, kayıt dışı ekonomi, iş̧̧i, işveren ve devlet bakımından önemli sakıncalar doğurmakta, kayıt dışı ekonominin bir türünü oluşturan suç faaliyetleri ülke ve toplumu çökertme noktasına getirmekte, söz konusu ekonominin kentlerde yoğunlaşması kent istihdamı ve çevresel açılardan sorunlara yol açmaktadır. Kayıt dışı ekonominin zararları konusunda halkta bilinç oluşturarak ona karşı önemli bir başarı kazanılacağı düşünülmektedir. Zira hangi tür önlemler alınırsa alınsın kayıt dışı ekonominin zararları konunda yeterli bir toplumsal bilinç uyandırılmazsa kayıt dışı ekonomiye karşı başarı kazanabilmek olanaksız değilse bile oldukça güçtür. Okuma alışkanlığının son derece zayıf, buna karşın televizyon seyretme alışkanlığının oldukça güçlü olduğu Türkiye'de televizyonlarda izlettirilecek kamu spotlarıyla kayıt dışı ekonominin zararları konusunda halkta bilinç oluşturulması, kayıt dışı ekonomiyle mücadelede başarı için yaşamsal bir önem taşımaktadır.

\section{A B S T R A C T}

Described different concepts, underground economy is one of the biggest problems that Turkey faces to it. Although informal economy gives immeasurable damages, one can enumerate the most important: The informal economy creates an obstacle on the way to full membership to EU, it makes the development impossible or very difficult by reducing tax revenue and disrupting GDP accounts. Again, informal economy gives significant damages for the employee, employer, and the state. Criminal activities, which constitute a kind of informal economy, bring the country and society to the point of collapse, the concentration of the aforementioned economy in cities causes problems in terms of urban employment and environmental issues. It is thought that a significant success will be gained against the uderground economy by creating public awareness about the damages of it. Inasmuch as it does not matter what kind of measures taken against it, without arousing public conscious on the damages of underground economy; the success against underground economy is very difficult if not impossible. In Turkey, the habitual of reading books is very thin, on the other hand, the habitual of watching television is very strong so public spots on the damages of underground economy must have been spectacled on television programs for the society. Establishing public conscious by public spots against the underground economy is a life and death matter to gain victory on it.

$\mathrm{K}$

ayıt dışı ekonomi; "saklı ekonomi”, "gizli ekonomi”, "yeraltı ekonomisi”, "enformel ekonomi”, "gölge ekonomi”, "yasadışı ekonomi", "kara ekonomi", "düzensiz ekonomi”, "beyan dışı ekonomi”, "nakit para ekonomisi” gibi çeşitli kavramlarla da ifade edilebilmektedir (Ilgın, 2002, s. 145). Kayıt dışı ekonomi, Türkiye'nin karşı karşıya kaldığı en önemli sorunlardan birisini oluşturmaktadır. Nitekim Onuncu Kalkınma Planının (2014-2018) Ekinde gösterilen Öncelikli Dönüşüm Programlarından birisi salt kayıt dışı ekonomi için özgülenmiş ve ismi de "Kayıt Dışı Ekonominin 
Azaltılması Programı” olmuştur. Bu programda; son yıllarda alınan önlemlere rağmen kayıt dışı ekonominin halen önemli sorun alanlarından birisi olduğu, kayıt dışı ekonomi alanının azaltılmasının, orta ve uzun dönemde ekonomik istikrar, gelir dağılımı ve istihdam gibi birçok makroekonomik unsurun iyileşmesine, ekonomide verimlilik düzeyi ve rekabet gücünün yükselmesine, ayrıca kamu gelirlerinin artmasına katkıda bulunacağı belirtilerek bu programla kayıt dışı ekonominin azaltılmasının amaçlandığı vurgulanmıştır. Ayrıca programda; kayıt dışı ekonominin GSYH'ye (Gayri Safi Yurtiçi Hâsıla) oranı ile tarım dışı sektörlerde kayıt dışı istihdam oranının beş puan azaltılması hedeflenmiştir (Onuncu Kalkınma Planı (2014-2018), 2013, s. 166).

Programın Bileşenleri ise Kayıt Dıı̧ı Ekonominin Boyutunun ve Etkilerinin Ölçülmesi; Denetim ve Yaptırımların Daha Etkili Kılınması; Kurumlar Arası Koordinasyon ve Veri Paylaşımının Artırılması; Kaçakçılıkla Etkin Mücadele Edilmesi ve Kayıt Dışılıkla Mücadelede Toplumsal Mutabakatın Sağlanması şeklinde saptanmıştır. Kayıt Dışılıkla Mücadelede Toplumsal Mutabakatın Sağlanması başlığı altında; toplumun ilgili kesimlerinin kayıt dış1lıkla mücadeleye aktif katılımının sağlanacağı, kamu idareleri ve STK'lar aracılığıyla kayıt dışı ekonominin olumsuz etkileri hakkında toplumsal bilincin artırılacağı ifade edilmiştir (Onuncu Kalkınma Planı (2014-2018), 2013, s. 167).

Gelir İdaresi Başkanlığının "koordinatör" kurum olduğu, Kayıt Dışı Ekonominin Azaltılması Programına dayalı olarak hazırlanan Eylem Planında ise "Kayıt Dışılıkla Mücadelede Toplumsal Mutabakatın Sağlanması" Bileşenin ismi "Eğitici ve Kapsayıcı Yöntemlerle Toplumun Tüm Kesimlerinde Farkındalığın Artırılması” olarak değiştirilmiş ve bu başlık altında çeşitli politikalara yer verilmiştir. Farkındalık artırılması politikaları olarak; kayıt dışılıkla mücadelede toplumun ilgili kesimlerinin katılımı sağlanarak, farkındalık ve bilinç artırma çalışmalarının yapılması; çocuklar başta olmak üzere, toplumda vergi ve sosyal güvenlik bilincini geliştirmek amacıyla görsel medyada yer alan programlardan faydalanılması; üniversite öğrencilerine yönelik her yıl yaz ve kış dönemlerinde düzenlenen eğitim seminerlerinde, gençlik kampları ve gençlik merkezlerinde "vergi bilinci” ve "sosyal güvenlik" konularında eğitimler verilmesi; işçi, işveren ve diğer sosyal tarafların kayıt dışı ekonomi ve onun bir parçası olan kayıt dışı istihdam konusunda bilinçlendirilmesi ve toplumsal farkındalığın artırılmasına yönelik faaliyetlerin kapsamının genişletilmesi şeklinde saptanmıştır (Onuncu Kalkınma Planı (2014-2018), 2015, s. 22-24). Onuncu Kalkınma Planının Kayıt Dışı Ekonominin Azaltılması Programında, kayıt dışılığın boyutunun ne olduğunun ortaya konulmaması isabetli olmamıştır. Gerçekten de Türkiye'de ekonomik faaliyetlerin önemli bir kısmının kayıt dışı olarak gerçekleştiği genel olarak kabul edilse de kayıt dışılığın boyutu konusunda yazarlar arasında bir oydaşı bulunmamaktadır. Nitekim bu durum, çeşitli yöntemlerle Türkiye'de kayıt dışılığın boyutunu ölçmeye yönelik çalışmaların sonuçlarının görüldüğü aşağıdaki tabloda açık bir şekilde görülmektedir.

Tablo 1: Türkiye'de Kayıt Dışılığın Boyutunu Ölçmeye Yönelik Çalışmalar

\begin{tabular}{|c|c|c|c|}
\hline Çalışma & Yöntem & Dönem & "Kayıt Dışı Ekonomi GSYH (\%) \\
\hline Çetintaş, Vergil (2003) ${ }^{1}$ & Ekonometrik Yaklaşım & 1971-2000 & $18-30$ \\
\hline Öğünç, Yılmaz (2000) & $\begin{array}{l}\text { Sabit Oran Yaklaşımı } \\
\text { Sabit Oran Yaklaşımı }\end{array}$ & 1960-1998 & $0-46$ \\
\hline Öğünç, Y1lmaz (2000) & $\begin{array}{l}\text { Sabit Oran Yaklaşımı } \\
\text { Vergi Yaklaşımı }\end{array}$ & $1968-2001$ & $31-84$ \\
\hline Us,(2004) & $\begin{array}{l}\text { Basit Elektrik Üretimi Yaklaşımı } \\
\text { Karma Elektrik Üretimi Yaklaşımı }\end{array}$ & $\begin{array}{l}1985-2001 \\
1978-2000\end{array}$ & $\begin{array}{c}26-184 \\
1-13\end{array}$ \\
\hline Schneider, ${ }^{2}$ Savaşan (2005) & Model Yaklașımı & $\begin{array}{l}1997-2003 \\
1999-2005\end{array}$ & $\begin{array}{c}5-64 \\
31-35\end{array}$ \\
\hline
\end{tabular}

\footnotetext{
${ }^{1}$ Çetintaş ve Vergil, 1971 ve 2000 yılları arasında Türkiye'de kayıt dışı ekonominin büyüklüğünü, IMF başekonomisti Tanzi'nin yönteminden yararlanılarak ekonometrik olarak tahmin etmişlerdir. Buna göre nakit para talebi kullanılarak yapılan bu çalışmada 2000 yılında kayıt dışı ekonominin resmi ekonomiye oranı \%24,7 olarak tahmin edilmiştir. 1971 yılında kayıt dışı ekonominin resmi ekonomiye oranı \%18,7 iken 1990’lı yıllardan itibaren bu oran hızla büyümüş, 1995 yılında \%31,2 olarak en yüksek seviyesine ulaşmış, 1998 yılında \%29,8, 1999 y1lında ise \%26,8 olarak gerçekleşmiştir. Fazla bilgi için bkz. Hakan Çetintaş ve Hasan Vergil, Türkiye'de Kayıtdışı Ekonominin Tahmini, Doğuş Üniversitesi Dergisi, 4 (1) 2003, s. 15-30.

2 Schneider'in "Çoklu Gösterge, Çoklu Nedenler" (Multiple Indicator, Multiple Causes, MIMIC) yöntemiyle yaptı̆̆ı başka bir çalışmaya göre, Türkiye'de kayıt dışı ekonominin GSYH'ye oranı 2003 yılında 32,2; 2004 yılında 31,5; 2005 yılında 30,7; 2006 yılında 30,4; 2007 yılında 29,1; 2008 y1lında 28,4; 2009 yilında 28,9; 2010 y1lında 28,3; 2011 yilında 27,7; 2012 y1lında 27,2; 2013 y1lında 26,5; 2014 y1lında 27,2; 2015 y1lında 27,8'dir. Bkz. Friedrich Schneider, Size and Development of the Shadow Economy of 31 European and 5 other OECD Countries from 2003 to 2015 : Different Developments, s. 7 (Bkz. http://www.econ.jku.at/members/Schneider/files/publications/2015/ShadEcEurope31.pdf, Erişim Tarihi, 15.03.2106).
} 
Kaynak: Sinan Ülgen ve Ulaş Öztürk, Kayıtdışı Ekonomi ve Sürdürülebilir Büyüme, TÜSİAD, İstanbul 2006, s. 58.

Ülgen ve Öztürk tarafından yapılan çalışmada gözden kaçırılsa da kayıt dışı ekonominin boyutları konusunda en ayrıntılı çalışmayı Ilgın gerçekleştirmiştir. Ilgın, Kayıtdışı Ekonomi ve Türkiye'deki Boyutları adlı DPT uzmanlık teziyle çeşitli yöntemlerle Türkiye'deki kayıt dışı ekonominin boyutlarını kestirmeye çalışmıştır. Yazar, yalnızca nakit para ile ödemelerin yapıldığı kayıt dışı ekonomik faaliyetlerin hacminin, 1975-1993 dönemi için kayıtlı GSYH'nin ortalama \%37'sini oluşturduğunu savlamaktadır. Yazar, 1990'lı yıllarda kayıt dışı ekonominin büyüklügünün ise daha yüksek seviyelerde olduğunu, 1992 yılında sadece nakit para kullanılarak gerçekleştirilen kayıt dışı GSYH'nin, parasal oran yöntemine göre kayıtlı GSYH'nin \%52,2'sini, ekonometrik parasal tahmin yöntemine göre ise ortalama \%47,2'sini oluşturduğunu savunmaktadır (Ilgın, 1999, s. 141).

Ilgın, kayıt dışı ekonomideki ödemelerde belirli ölçüler çerçevesinde bankalar sisteminden yararlanıldığı düşünüldüğünde, söz konusu oranların daha da büyüdügünü savlamaktadır. Yazar, örnek olarak, kayıt dışı işlemlerde yapılan ödemelerin 1/4 oranında çek yazmak ve banka kartıyla ödemek veya hesaptan para çekerek ödemek gibi vadesiz hesaplardan yararlanılarak yapıldığı varsayıldığında, kayıt dışı ekonominin, kayıtlı GSYH’ye oranının, 1975-1993 döneminde ortalama \%59,0, 1993 yılında ise \%94,8 olduğunu, kayıt dış1 işlemlerde mevduatlardan yararlanma durumunun $1 / 3$ oranında olması durumunda ise bu oranların sırasıyla \%73,8 ve \%124,5 seviyesine ulaştığını, bu sonuçların ülkemizde "ekonominin yarısının yeraltında" olduğu savını doğruladığını belirtmektedir (Ilgıı, 1999, s. 142-143).

Ilgın, ülkede özellikle gelir vergisi kaçaklarının çok yüksek boyutlarda olduğunu, vergi denetim sonuçlarından yararlanılarak yapılan hesaplamalarda, 1960-1993 döneminde kaçırılan gelir vergisi miktarının, tahsil edilen miktarın ortalama \%139,2'si olduğunu belirtmektedir. Yazar, kurumlar vergisinde \%46,5, diğer dolaysız vergilerde ise \%59,9 olarak tespit edilen söz konusu oranının, toplam dolaysız vergilerde \%121,5 olarak gerçekleştiğini belirtmektedir. Yazar, denetim sonuçları çerçevesinde dolaylı vergilerdeki kaçağın göreceli olarak düşük görüldüğünü, 1960-1993 yılları arasında yurtiçi dolaylı vergilerdeki saptanan kayıt dış1ık oranının \%21,8 olarak bulunduğunu ifade etmektedir. Bununla birlikte Ilgın, yasal ve efektif KDV vergi oranları sektörel olarak incelendiğinde ve 500 büyük sanayi kuruluşunun ülkemizde yaratılan toplam katma değerin yaklaşı \%13'ünü yaratmasına rağmen, tahsil edilen toplam KDV'nin yaklaş1k \%50'sini ödediği göz önünde tutulduğunda, dolaylı vergilerdeki kaçağın da önemli boyutlarda olduğunun görüldüğünü savunmaktadır (Ilgın, 1999, s. 143).

Kayıt dışı ekonomi ile ilgili ikinci çalışmasında Ilgın, söz konusu ekonominin boyutlarını daha da güncellemiştir. Yazar, 1968-2001 döneminde kayıt dışı GSYH'nin kayıtlı GSHY'ye oranının ortalama olarak \%45 olduğunu, 1981-1990 döneminde ortalama \%35,6 iken, 1991-2001 döneminde artarak ortalama \%64,4'e çıktığını belirtmektedir. Yazar, kayıt diş1 ekonominin yıllar itibarıyla artış eğilimi gösterdiğini, 1994 krizi sonrası yıl olan 1995 yılında \%84'e çıktığını, 2000 yılında \%54'e düştükten sonra yine bir kriz yılı olan 2001 yılında tekrar artarak kayıtlı GSYH'nin \%66,2'sine ulaştığını savunmaktadır (Ilgın, 2002, s. 151).

Ilgın, Maliye Bakanlığı denetim görevlilerince 1985-2001 döneminde yapılan vergi incelemeleri sonucu bulunan matrah farklarının, söz konusu dönem ortalaması olarak, vergi mükelleflerinin beyan ettikleri vergiye tabi gelirlerinin \%65,7'si kadarını vergi yetkililerinden gizlediğini gösterdiğini, 1985-2000 döneminde matrah farkı oranlarının \%25,9 ila \%129,5 arasında değiştiği, kriz yılı olan 2001 yılında ise \%184,3'e kadar ulaştığını belirtmektedir.

Yazar, kayıtsız GSYH’nin bunalım veya istikrar programı yılı sıkı para politikası sonrasında firladığını da savlamaktadır (Ilgın, 2002, s. 151-152). Yine Maliye Bakanlığı Hesap Uzmanları Kurulu tarafından (1998-2004) yıllarını kapsayan bir araştırmada kayıt dışı ekonominin GSYH'nin \%26 ila \%37'sini oluşturduğu saptanmıştır (Sugözü, 2010, s. 178). Görüldüğü üzere kayıt dışı ekonominin boyutunu ölçmeye yönelik çalışmalarda söz konusu ekonominin boyutlarının Gayri Safi Yurtiçi Hâsılanın (GSYH) önemli bir kısmını oluşturduğu ortaya çıkmaktadır. ${ }^{3}$ Bunun gibi, ülkede, kayıt dışı istihdam oranları bakımından da yüksek oranlar görülmektedir. Gerçi son yıllarda kayıt dışı istihdam oranı yıllara göre azalış gösterse de oran hala yüksekliğini korumaktadır. Gerçekten de 2009 yılında kayıt dışı istihdam oranı \%43,8, 2010 yılında \%43,3, 2011 yılında \%42,1, 2012 yılında \%39,0, 2013 yılında \%36,8, 2014 yılında \%35,0 olarak gerçekleşmiştir (http://www.sgk.gov.tr: 11.04.2016).

\footnotetext{
${ }^{3}$ Ahmet Fazıl Özsoylu tarafından 1990 yılı temel alınarak bir yapılan bir çalışmada kayıt dışı ekonominin GSYH'nin \%7,5'ini oluşturduğu saptanmıştır. Bkz. Sarıkaya, s. 42. Kayıt dışı ekonominin boyutları dikkate alınınca bu saptamanın inandırıcı olduğunu düşünmemekteyiz.
} 
2014 yılında tarım sektöründe kayıı dışı oranı \%82,3 iken, tarım dışı sektörlerde bu oran \%22,3 olarak gerçekleşmiştir (www.tuik.gov.tr). 2015 yılı sonu itibarıla kayıt dışı istihdam oranı \%33,6 olarak gerçekleşmiş, bu oran tarım sektöründe \%81,2 iken, tarım dışı sektörlerde \%21,2 olarak gerçekleşmiştir (www.tuik.gov.tr). Görüldüğü üzere Türkiye'de gerek kayıt dışı ekonomi, gerekse kayıt dışı istihdam oldukça yüksek oranlarda seyretmektedir. Kayıt dışı ekonominin GSYH'ye oranı konusunda Ilgın'ın görüşünü dikkate alarak bu oranı ortalama $\% 65^{4}$ veya Türk bürokrasisinde büyük itibar gören Schneider'ın ${ }^{5}$ saptadığ1 \%27 olarak kabul etsek bile ileride bahsedilecek olan ekonomik olarak gelişmiş batı ülkelerinin oranlarına kıyasla makul kabul edilemez.

Yine Onuncu Kalkınma Planının Ekinde gösterilen Kayıt Dışı Ekonominin Azaltılması Programında; kayıt dışı ekonominin GSYH'ye oranı ile tarım dışı sektörlerde kayıt dışı istihdam oranının beş puan azaltılmasının hedeflenmesi de isabetli bir yaklaşım olmamıştır. Bir kere kayıt dışı ekonominin GSYH'ye oranının 5 puan azaltılması yoluyla AB ortalaması yakalanamaz. Gerçekten de Schneider'ın yaptığı hesaplamalara göre 2003-2015 yılları arasında 28 AB üyesi ülkenin kayıt dışı ekonomisinin GSYH'ye oranlarının ortalaması 2003 yılında 22.6, 2004 yılında 22.3, 2005 y1lında 21.8, 2006 y1lında 21.1, 2007 y1lında 20.3, 2008 yılında 19.6, 209 y1lında 20.1, 2010 yılında 19.9, 2011 y1lında 19.6, 2012 y1lında 19.3, 2013 yılında 18.8, 2014 yılında 18.6, 2015 yılında 18.3'dür (Schneider, 2015, s. 6).

Yukarıda belirtildiği üzere anılan yazarın söz konusu yıllar bakımından Türkiye açısından yaptığı hesaplamalara göre bu oranlar; 32.2, 31.5, 30.7, 30.4, 29.1, 28.4, 28.9, 28.3, 27.7, 27.2, 26.5, 27.2, 27.8'dir. Görüldüğü üzere 2003-2015 y1llar1 arasında hangi yıl dikkate alınırsa alınsın Türkiye'de kayıt dışı ekonominin boyutu beş puan azaltılsa bile AB ortalamasının yakalanması olanaksızdır. Kayıt dışı ekonominin boyutu açısından AB ortalamasının yakalanabilmesi için kayıt dışı ekonominin GSYH'ye oranının yaklaşık 10 puan azaltılmasının öngörülmesi gerekirdi.

Kayıt Dışı Ekonominin Azaltılması Programında; tarım dışı sektörlerde kayıt dışı istihdam oranının beş puan azaltılmasının amaçlanması da doğru bir tutum olmamıştır. Zira Türkiye'de tarım dışı sektörlerde kayıt dışı istihdam oranı, tarım sektörüne kıyasla göreceli olarak düşük olduğundan asıl olarak tarım sektöründe kayıt dışı istihdam oranının azaltılması ve bu doğrultuda önlemler alınması gerekirdi. Gerçekten de yukarıda belirtildiği üzere 2015 yılı sonu itibarıyla Türkiye'de tarım kesiminde kayıt dışı istihdam oranı yaklaşık \%81 civarında bulunmaktadır. Gelişmiş hiçbir batı ülkesinde rastlanılamayacak derecede ${ }^{6}$ yüksek olan bu orana Türkiye'nin uzun erimde katlanabilmesi olanaksızdır. Zira tarım dışı sektörlerde kayıt dış1 istihdamdan doğabilecek bütün risk ve zararlar tarım sektöründe geçerli olan kayıt dışı istidam bakımından da geçerli bulunmaktadır. ${ }^{7} \mathrm{Bu}$ açıdan yalnızca tarım dışı sektörlerde değil tarım sektöründe de kayıt dışı istihdam oranının azaltılacağının öngörülmesi gerekirdi. ${ }^{8}$ Bunun yapılmaması büyük bir eksiklik olarak göze çarpmaktadır.

Gerek Onuncu Kalkınma Planının Ekinde gösterilen "Kayıt Dışı Ekonominin Azaltılması Programının bileşenlerinden birisini oluşturan "Kayıt Dışılıkla Mücadelede Toplumsal Mutabakatın Sağlanması” başlığı altında gerekse bu programa dayalı olarak hazırlanan Eylem Planının Eğitici ve Kapsayıcı Yöntemlerle Toplumun Tüm Kesimlerinde Farkındalığın Artırılması ${ }^{9}$ başlı̆̆ı altında kayıt dışı ekonominin olumsuz zararları konusunda toplumsal bilincin artırılacağından

\footnotetext{
${ }^{4}$ Kanımızca yazarın kayıt dışı ekonominin 1991-2001 döneminde ortalamasının GSYH’nin \%64,4'üne ulaştığı, 1985-2001 döneminde yapılan vergi incelemeleri yöntemiyle mükelleflerinin beyan ettikleri vergiye tabi gelirlerinin \%65,7'sini vergi yetkililerinden gizlediğini saptadığına göre bu rakamları günümüze kadar uzatmak olanaklıdır. Zira 2000’li yıllardan bu yana kayıt dışı ekonomiye karşı etkili ve köklü önlemler alınamadığına göre söz konusu oranların üç aşağı beş yukarı aynen sürdüğünü savlamak olanaklıdır.

5 Örneğin dönemin Maliye Bakanı Mehmet ŞİMŞEK tarafindan 10 Eylül 2013 tarihinde "Combatting Shadow Economy-Turkish Experience" adlı uluslararası bir $\quad$ sunumda $\quad$ Schneider'ın çalışmaları temel alınmıştır. http://www.maliye.gov.tr/KonusmaSunumlari/sunummerkezi/index.html?ktp=CSETe,Erişim Tarihi, 15.03.2016.

${ }^{6}$ Kayıt dışı ekonomiyle ilgili uluslararası istatistiklerde ayrı bir kayıt dışı istidam oranı şeklinde bir veri bulunmamakta, kayıt dışı istidam, kayıt dışı ekonominin boyutları içerisine sokularak genel bir kayıt dışı ekonomi oranı verilmektedir.

${ }^{7}$ İleride anlatılacağı üzere kayıt dışı istidam bakımından işçi, işveren ve devlet açısından doğabilecek bütün olumsuz sonuçlar gerek tarım sektörü gerekse tarım dışı sektörlerde görülen kayıt dışı istihdam açısından da geçerlidir. Bundan da öte tarım dışı sektörlerde görülebilecek olan iş kazaları ve meslek hastalıkları riskleri, tarım sektöründe de görülebilmektedir. Örneğin meyve toplayan bir işçi ağaçtan düşerek geçici veya sürekli iş göremez bir konuma gelebilir. Yine tarlada çalışan bir işçi zehirli bir yılan veya akrebin sokması sonucu yaşamını kaybedebilir. Ayrıca, sürgit bir şekilde zehirli tarım ilaçları kalıntısına temas eden bir işçi ölümcül kanser hastalığına yakalanabilir.

${ }^{8}$ Kayıt dışı istihdamın azaltılması hedefleri bakımından genel nitelikli kayıt dışı ekonominin azaltılması hedefinden ayrı bir hedef belirtmeye gerek bulunmadığından ve AB'nin kayıt dışı ekonomisinin GSYH'ye oranı son yıllarda \%18 civarında olduğundan kayıt dışı istihdamın da gerek tarım sektöründe gerekse tarım dişı sektörlerde \%18 civarına düşürülmesinin erek olarak benimsenmesi isabetli olacaktır.

${ }^{9}$ Yukarıda belirtildiği üzere Kayıt Dışı Ekonominin Azaltılması Programının "Kayıt Dışılıkla Mücadelede Toplumsal Mutabakatın Sağlanması" bileşeninin ismi, Eylem Planında "Eğitici ve Kapsayıcı Yöntemlerle Toplumun Tüm Kesimlerinde Farkındalığın Artırılması” şeklinde değiştirilmiştir.
} 
bahsedilmesine karşın kayıt dışı ekonominin söz konusu zararlarından ismen bahsedilmemesi de büyük bir eksikliktir. Aşağıda ayrıntılı bir şekilde gösterildiği üzere kayıt dışı ekonominin ekonomik, sosyal ve kültürel çok çeşitli zararları bulunmaktadır. Kayıt dışı ekonomiye karşı toplumsal bilincin oluşturulması ve artırılması ancak söz konusu zararların neler olduğu konusunda fikir sahibi olunmakla gerçekleştirilebilir. Bu bağlamda gerek Programda gerekse Eylem Planında kayıt dışı ekonomi alanının Avrupa ülkelerine göre yüksek olduğu, bu alanın büyümesinin, AB'ye tam üyelik hedefinin gerçekleştirilmesini güçleştirdiği, istatistikî hesapları bozduğu, bireyler ve işletmeler arasında haksız rekabetin doğmasına, gelir dağılımının bozulmasına, organize suçun büyümesine, mükelleflerin ödeme isteğinin azalmasına neden olduğu, kayıt dışı ekonominin yaygınlaşmasının, bu sorunun toplum tarafindan meşru bir olgu olarak algılanmasına ve böylelikle toplumsal değerlerin ve ahlakın zedelenmesine yol açtığı gibi kayıt dışı ekonomiden doğan olumsuz sonuçlar en azından kavramsal olarak bahsedilseydi oldukça isabetli hareket edilmiş olunurdu.

Bu çalışmanın ilk kısmında kayıt dışı ekonomiye karşı halkın etkin bir şekilde bilinçlenebilmesi için söz konusu ekonominin zararları üzerinde durulacaktır. Çalışmanın ikinci kısmında ise halkta kayıt dışı ekonomiye karşı oluşturulması gereken farkındalığın yöntemi üzerinde durulacaktır.

\section{KAYIT DIŞI EKONOMININ ZARARLARI}

Aşağıda ayrıntılı bir şekilde üzerinde durulacağı üzere kayıt dışı ekonominin ekonomik, sosyal ve kültürel açıdan birçok olumsuz sonuçları bulunmaktadır. Kayıt dışı ekonominin bu olumsuz sonuçları arasındaki ayrımın kesin ve katı bir nitelik taşımaması nedeniyle söz konusu ekonominin olumsuz sonuçlarının "ekonomik", "sosyal” ve "kültürel” açıdan sert ve katı bir şekilde sınıflandırılması yerine "tadadi" (gösterme yoluyla) bir şekilde gösterilmesi yoluna gidilmiştir. ${ }^{10}$

\subsection{Kayıt Dışı Ekonominin AB'ye Tam Üyelik Yolunda Engel Oluşturması}

Türkiye'nin mevcut durumda $\mathrm{AB}$ karşısındaki konumu “müzakereci ülke” (accession country) konumudur. AB ile müzakerelerin başarısı birçok açıdan Türkiye'de kayıt dışılığın azaltılmasına bağlıdır. Gerçi AB ile müzakerelerde doğrudan kayıt dışılık ile ilgili bir başlık bulunmasa da malların serbest dolaşımından rekabet politikasına, tarım politikasından sanayi politikasına uzanan birçok başlık temelde kayıt dışı ekonomi ile yakından ilgilidir. Türkiye'de kayıt dış1lık günümüzdeki yaygınlığını koruduğu ölçüde birçok AB müktesebatının yeterli ölçüde uygulanabilmesi olanaklı değildir. Daha açık bir deyişle, tam üyelik müzakerelerinde açılan başlıkların kapanması, bu başlıklar altındaki mevzuatın uygulamaya geçirilmesi koşuluna bağlı olduğundan Türkiye'de kayıt dışı ekonominin boyutlarının yüksek olması, müzakerelerin ilerlemesi bakımından bir engel oluşturmaktadır (Ülgen ve Öztürk, 2006, s. 5).

Kayıt dışı ekonomi, müzakere başlıklarını ilgilendiren bir sorun olmasının ötesinde, müzakerelerin genelini de ilgilendiren bir konu niteliğini taşımaktadır. Gerçekten de tam üyelik müzakerelerinin en görünür etkisi, Türkiye'nin AB müktesebatını üstlenmesi, gerekli mevzuat değişikliğini yapması, değişen mevzuatı da fiilen uygulaması şeklinde olacaktır. Müzakerelerin ilerleyebilmesi için mevzuat değişikliğinin yapılması da tek başına yeterli olmamakta, bunun yanında eşanlı olarak söz konusu mevzuatın yaşama geçirilmesi ve alanda uygulanmasının sağlanması gerekmektedir. Konuya bu açıdan yaklaşıldığında, kayıt dışılığın boyutuyla $\mathrm{AB}$ ile tam üyelik müzakerelerinin başarısı arasında bir çelişki olduğu görülecektir. Nitekim Türkiye'de kayıt dış1 ekonominin oldukça yüksek olarak seyretmesi yüzünden tam üyelik müzakerelerinde ilerleme tehlikeye girmiştir. Somut bir deyişle, ülkede kayıt dışı ekonominin yüksekliği, ekonominin belirli bir bölümünün kamu idaresinin denetimi dışına çıktığının bir göstergesini oluşturmakta, bu bağlamda, söz konusu yükseklik, Türkiye'nin hukuk devleti olma özelliğini sorgulanır duruma getirmektedir. Zira kamu kesimi, siyasi irade noksanlığı veya kurumsal kapasite eksikliği nedeniyle kayıt dışı ekonominin bulunduğu alanlarda denetim işlevini yerine getirememektedir (Ülgen ve Öztürk, 2006, s. 5).

Kayıt dışı ekonomi, hukuk devleti ilkesini erozyona uğratan bir olgu olduğundan $\mathrm{AB}$ açısından bu olguya göz yumulması olanaksızdır. Gerçekten de 2 Ekim 1997 tarihli Amsterdam Antlaşmasının 8. maddesiyle Avrupa Birliğini kuran Maastricht Antlaşmasının F maddesinin 1. fikrası değiştirilerek; AB'nin özgürlük, demokrasi, insan hakları ve temel özgürlüklere sayg1 ve "hukuk devleti" (rule of law) ile üye ülkeler tarafından benimsenen ortak hukuk prensipleri üzerine kurulduğu açıkça ifade edilmiştir. Bu hükümden anlaşlacağı üzere AB'nin kuruluş temellerinden birisini hukuk devleti ilkesi oluşturur. Bununla birlikte kayıt dışı ekonominin yaygın olması yüzünden Türkiye'de hukuk devleti ilkesinin yaşama geçirilmesi bağlamında

\footnotetext{
${ }^{10}$ Çalışmanın hacmini gereksiz yere genişletmemek için kayıt dışı ekonominin tüm zararları üzerinde durulması yerine belli başlı zararları üzerinde durulmuştur.
} 
önemli sorunlar bulunmaktadır. Zira kayıt dışı ekonominin yaygın olması, az önce belirtildiği üzere ekonominin belirli bir kesiminin hukuk kuralları ve kamu idaresinin denetimi dışına çıktığının göstergelerini oluşturur. Bir ülkede hukuk devleti ilkesinin gerçek anlamda uygulandığından söz edilebilmesi için herkesin hukuk kurallarına tabi olması ve bu bağlılığın denetlenmesi gerekir. Türkiye'de yaygın bir şekilde kayıt dışı ekonomi olgusuna rastlanması, hukuk devleti ilkesinin uygulamaya geçirilmesi bakımından büyük kaygılara yol açmakta, bu husus ise AB açısından hoş görülmemektedir. Zira az önce de belirtildiği üzere AB'nin üzerine kurulduğu ilkelerden birisini hukuk devleti ilkesi oluşturmaktadır. Hukuk devleti ilkesinin tam olarak yaşama geçmediği bir durumda Türkiye'nin her faslı başarıyla tamamlasa bile AB'ye tam üye olması ham bir hayalden öteye geçemeyecektir. ${ }^{11}$

\subsection{Kayıt Dışı Ekonominin GSYH Hesaplarını Bozması ve Bunun Sonuçları}

Kayıt dışı ekonomi gerçekte "başıboş ekonomi” (free economy) niteliğini taşımakta olup ekonominin; devlet düzenlemelerine, müdahalelerine, vergiye ve diğer yükümlülüklere tabi olmadan işlemesi anlamını taşır (Bowden, 1996, s. 15). Kayıt dışı ekonomi doğası gereği GSYH hesaplarında yer alamamaktadır.

Gerçekten de kayıt dışı ekonominin bir kısmını yasal faaliyetler oluşturmakta olup bu faaliyetlerde görülen "vergi kaçırma" (tax evasion) doğal olarak GSYH hesaplarında yer almamaktadır. Örneğin, bir lokantada yenilen yemek için verilen nakit para üzerine lokanta sahibinin fiş veya fatura kesmemesi, garson, taksici veya valenin kendisine verilen bahşişi maliyeye bildirmemesi, çocuk bakıcıları, ev temizlikçilerinin kendilerine verilen ücreti beyan etmemeleri veya riskli işleri yapanların (örneğin bina yıkımında çalışanların) beyandan kaçınmaları durumunda ekonomik eğer taşıyan mal ve hizmetler GSYH hesaplarında görülemez (Bowden, 1996, s. 136).

Kayıt dışı ekonominin diğer türünü oluşturan yasadışı faaliyetler de doğası gereği GSYH hesaplarında yer alamamaktadır. Örneğin bir uyuşturucu satıcısı, fuhuş için yer temin eden kişi, fahişe, kumarbaz, ihale fesatçısı hizmet ve kazancını bildirmekten kaçınır. Zira bu hizmet ve kazancın bildirilmesi durumunda kişi başının belaya gireceğini düşünür. Bu tür faaliyetlerin kanun veya genel ahlak kuralları gereğince yasaklanmış olması onların hizmet ve kazancının ekonomik bir değer taşımadığı anlamına gelmez. Zira ortada talep edilen ve ekonomik olarak değer taşıyan ürün ve/veya hizmet bulunmaktadır. Ancak ekonomik nitelik taşısa da bu ürün ve/veya hizmetler GSYH hesaplarına girmemektedir (Bowden, 1996, s. 136).

Kayıt dışı ekonomik faaliyetlerin GSYH hesaplarında yer almamasının bir takım olumsuz sonuçları bulunmaktadır. Bir kere kayıt dışı ekonomik faaliyetler sonucu elde edilen gelir, bildirilmediği için kişi başına düşen gelirin ne olduğu tam olarak bilinemez. Bundan dolayı da kişi başına geliri artırıcı politikaların başarılı olması oldukça güçleşir. Nitekim Türkiye'de kişi başına düşen geliri artırıcı politikaların başarısızlığının temel nedenini kayıt dışı ekonominin yoğunluğu oluşturur.

İkinci olarak, kayıt dışı ekonomik faaliyetler sonucu elde edilen çıktı GSYH hesaplarına girmediği için GSYH'nin ne olduğu tam olarak bilinemez. GSYH'nin tam olarak bilinememesi genel büyüme oranlarını bozmakta ve ekonomide neler olup bittiğinin anlaşılamamasına ve böylelikle ekonomi açısından gerçekçi olmayan bir bakışa yol açmaktadır (Bowden, 1996, s. 15). Gerçekten de kayıt dişı ekonomiden dolayı oluşan ürünlerin GSYH hesabına katılamaması genel büyüme oranının tam olarak bilinememesine yol açmakta, böylelikle ülkenin büyümesini sağlayıcı gerçekçi politikalar ortaya konulamamaktadır. Bir başka deyişle, ekonominin kayıt içi ve kayıt dışı diye ikiye bölünmesi sonucu, ekonomi, verimli ve zenginlik üreten bir yapıya kavuşamamakta, ekonomik veriler ve bu bağlamda GSYH verilerinin açıklama gücü azalmakta veya bozulmaktadır. Kayıt dışı ekonominin veriler üzerindeki bu olumsuz etkisi GSYH'nin artırılmasını sağlayıc1 ${ }^{12}$ politikaların üretilememesine neden olmaktadir.

Üçüncü olarak, kayıt dışı ekonomik faaliyetlerde istihdam sağlanmış olmasına karşın bu durum istihdam verilerine yansımamaktadır. Böylelikle istihdam verilerinin açıklama gücü azalması veya bozulmaktadır. İstihdam verilerinin açıklama gücünün azalması veya bozulması ise hem gerçek GSYH hesaplarının hem de doğru bir şekilde işsizlik oranının

\footnotetext{
${ }^{11}$ Krş. Hasan Dursun, Nasıl Bir Yargı Reformu, Adalet Yayınevi, Ankara 2009, s. 190 vd. Aslında AB’ye tam üye olmayı siyasal erek olarak benimsemiş olan bir ülkenin, bu ereğin gerçekleşmesini engelleyici en önemli faktörün kayıt dışı ekonomi olduğu gerçeğini görmezden gelmesi hiçbir şekilde kabul edilemez. Krş. Ülgen ve Öztürk, s. 6

12 Burada kastedilen GSYH artışından kastedilen husus; yasal ekonomik faaliyetler bakımından artıştır. Gerçekten de ancak yasal ekonomik faaliyetler bakımından artış ve genişleme toplumun maddi gönencini artırmaktadır. Yasa dışı faaliyetlerin artış ve genişlemesi hiçbir şekilde toplumun maddi gönencine hizmet etmez. Örneğin uyuşturucu ekim alanlarının çoğalması, erişkin veya yetişkin bir kişiye uyuşturucu satılması toplumun maddi gönencine hizmet etmek şöyle dursun söz konusu gönenci azaltıcı bir etki doğurur. Krş. Paul R. Gregory ve Roy J. Ruffin, Basic Macroeconomics, Scott, Foresman and Company, USA 1989, s. 140.
} 
saptanamamasına yol açmaktadır (Gregory ve Ruffin,1989:140). Kayıt dışı ekonomi yüzünden işsizlik oranının doğru bir şekilde hesaplanamaması yüzünden işsizliği önleyici nitelikte ekonomik ve sosyal nitelikte etkin "siyasalar" (policies) oluşturulamamaktadır (Sekizinci Beş Yıllık Kalkınma Planı, 2001, s. 1).

Son olarak, kayıt dışı ekonominin GSYH hesaplarında görülememesi Türkiye’yi “ikili” (dualist) bir ekonomik yapıya mahkûm etmekte, ekonominin verimsiz yapısını koruyarak onun küresel olarak daha verimli bir nitelik kazanmasını engellemektedir. Bu durumun Türkiye'nin daha "gönençli” (müreffeh) bir geleceğe yol almasını zorlaştırdığı ortadadır ( Ulaş ve Öztürk, 2006, s. 152).

\subsection{Kayıt Dışı Ekonominin Vergi Gelirlerini Azaltması ve Bunun Sonuçları}

Az önce belirtildiği üzere kayıt dışı ekonominin temel niteliklerinden birisini söz konusu ekonominin vergisel yükümlülüklere tabi olmadan işlemesi oluşturur. Gerçekten de gölge ekonomisi, temel olarak vergi kaçırma güdüsü ile yasa dışı faaliyetleri gizlemek gereksiniminden doğmuştur (Schiller,1991: 89). Bu durum kayıt dış1 ekonominin devletin vergi gelirlerini azaltacağını açık bir şekilde ortaya koymaktadır (Bowden, 1996, s. 15).Kayıt dışı ekonominin yoğunluğu yüzünden Türkiye yıllık olarak yaklaşık 10 milyar Avroluk bir zarara uğramaktadır. ${ }^{13}$

Kayıt dışı ekonominin vergi gelirlerini azaltması oldukça önemli bir takım olumsuz sonuçlara yol açmaktadır. Bunlardan ilki, vergi gelirlerinin azalması sonucu devlet ya vergi oranlarını artıracak ve/veya ek vergi koyacak ${ }^{14}$ veya borçlanma ${ }^{15}$ yapacaktır. Bu durumlarda ise ülkenin geleceği çalınmış olacaktır. ${ }^{16}$ İkinci olarak, kamunun vergi gelirlerinin azalması sonucu yoksullara mali transferler yapılamayacak ve böylelikle gelir dağılımındaki bozukluk daha da çok artacaktır.

\subsection{Kayıt Dışı İstihdamın İşçi, İşveren ve Devlet Bakımından Doğan Sakıncaları}

Kayıt dışı ekonominin bir boyutunu oluşturan kayıt dışı istihdamın ülke ekonomisine ve kişilere verdiği inanılmaz zararlar bulunmaktadır. Bu başlık altında kayıt dışı istihdamın işçi, işveren ve devlete verdiği olumsuz sonuçları incelenecektir.

Kayı1t dışı ekonomiden en fazla zarar gören kesim işçi kesimidir. Her şeyden önce bir işçi kayıt dışı çalışırsa sağlık kuruluşlarına yeterli ve gerekli ölçüde başvuramayacağından yeterli ve gerekli sağlık yardımı alamamakta, bu durum ise onun hastalık vakalarının artmasına yol açmaktadır. Bu durum tüm kayıt dışı çalışanlar açısından bütünsel düşünüldüğünde ise sağlıksız bir toplumun oluşmasına zemin hazırlanması anlamını taşır. Öte yandan kayıt dışı çalışan bir işçi, iş kazasına uğraması veya meslek hastalığına yakalanması veya kadın bir işçinin anne olması halinde sosyal güvenliği olmadığı için hak ve yardımlardan faydalanamaması olgusuyla karşılaşılacaktır ki bunun ne kadar büyük sakıncalar doğuracağı ortadadır. Kayıt dışı çalışan bir işçi, az önce belirtildiği üzere yeterli sağlık yardımı alamayacağı için kısa vadede, hastalığı sürekli bir biçimde artacak, uzun vadede, bir başka deyişle, çalışamaz duruma geldiğinde ise emekli aylığı alamadığı için yoksul bir konuma gelecektir. Kayıt dışı çalışanın uzun vadede emekli aylığı alamamasının yalnızca kendisine zararı olmayacak, onun

\footnotetext{
${ }^{13}$ Daha doğru bir deyişle ülkede kayıt dişı ekonominin yoğunluğu aşama aşama düşürülse bile 10 yıl içerisinde vergi gelirlerinde "birikmiş" (kümülatif) olarak yaklaşık 100 milyar Avroluk bir artış sağlayacağı hesaplanmaktadır. Eğer kayıt dışı ekonomi bütünüyle ortadan kaldırılırsa vergi gelirlerinde görülen artış bundan çok daha fazla olacaktır. Bkz. Ulaş ve Öztürk, s. 5, 143-144.

${ }^{14}$ Kayıt dışı ekonomi yüzünden vergi gelirlerinin azalması sonucu Devletin vergi oranlarını artırması ve/veya ek vergi koymasının yatırımlar ve "yerüstü ekonomisi" (above-ground economy) bakımından vahim bir sonucu bulunmaktadır. Zira devletin vergi bakımından aldığı bu önlemler yüzünden yatırım ve yerüstü ekonomisiyle ilgili kararlar "ekonomik etkinlik" (economic efficiency) ilkesine göre değil vergi yükümlülüğü dikkate alınarak verilecektir. Bkz. Bowden, s. 611. Yine ek vergi ve/veya artırılan vergi oranları kısır bir döngüye de yol açmaktadır. Gerçekten ek vergi ve/veya artırılan vergi oranları kayıtlı çalışan kesim üzerinde vergi yükünü ağırlaştırmakta ve kayıtdışılığı teşvik eden bir unsur oluşturmaktadır. Böylelikle artan vergiler ve sürekli büyüyen kayıt dışı ekonomi şeklinde bir kısır döngü ortaya çıkmaktadır. Bkz. Ulaş ve Öztürk, s. 42.

${ }^{15}$ Vergi gelirlerindeki azalma nedeniyle devletin borçlanmasının da birçok dezavantajı bulunmaktadır. Borçlanma sonucunda iç piyasada faizler yükselmekte ve bu yükselmenin sonucunda da yatırımlar azalarak hem milli gelir hem de istihdam olumsuz etkilenmektedir. Bkz. Ulaş ve Öztürk, s. 43.

16 Ülkenin geleceğinin çalınmasının ana nedenini kamusal hizmetlerin yetersizliği oluşturur. Zira kayıt dışı ekonominin artması sonucunda vergi ve sosyal güvenlik katkı yükü ile düzenlemelerin yoğunluğunun artacak, buna karşın kamusal hizmetler nicel ve nitel yönlerden düşecektir. Friedrich Schneider, Shadow Economy in Turkey and in other OECD-Countries: What do we (not) know?, (http://www.gep.gov.tr/tmp/BSEC\%20pdf/Prof.\%20Dr.\%20Friedrich\%20Schneider\%20ShadEc_Turkey2012.pdf Erişim Tarihi, 15.3.2106), Ülkenin geleceğinin çalınmasının ana nedenini kamusal hizmetlerin yetersizliği oluşturur. Zira kayıt dışı ekonominin artması sonucunda vergi ve sosyal güvenlik katkı yükü ile düzenlemelerin yoğunluğunun artacak, buna karşın kamusal hizmetler nicel ve nitel yönlerden düşecektir. Friedrich Schneider, Shadow Economy in Turkey and in other OECD-Countries: What do we (not) know?, (http://www.gep.gov.tr/tmp/BSEC\%20pdf/Prof.\%20Dr.\%20Friedrich\%20Schneider\%20ShadEc_Turkey2012.pdf Erişim Tarihi, 15.3.2106), s. 11.
} 
eş ve çocukları da zarara uğrayacaktır. Kayıt dışı çalışanın ölümü halinde bile mağduriyetler bitmeyecektir. Zira çalışanın ölümü halinde onun eş ve çocukları ölüm yardımı alamayacak ve onlara aylık bağlanamayacaktır (http://www.sgk.gov.tr, 11.04.2016).

$\mathrm{Bu}$ zararlarının dışında kayıt dışı ekonominin bizzat kendisi işçiler için kanımızca sefalet anlamını taşır. Gerçekten de kayıt dışı istihdam, kayıt içi sektör aleyhine haksız rekabete yol açması yüzünden kayıtlı sektör işçi atmaya başlar. Bunun üzerine işinden atılan işçiler, kayıt dışı kesimde iş aramaya başlarlar. İş arayan kişilerin fazla olması istihdam piyasasında arz fazlalığına yol açar. İşçi arzının fazlalığının bizatihi kendisi ise ücret düşüklüğü ve yoksulluk anlamını taşır (Siggel, 2010 , s. 93).

Kayıt dışı ekonominin işçiler açısından en önemli zararlarından birisi de bu ekonominin çocuk işçiliğine yol açmasıdır. 18 yaşından küçük çocukların çalıştırılması onların ruhsal, sosyal ve fiziki gelişimi açısından inanılmaz zararlar verir (Ilgın, 1999, s. 44-45) ve durum sağlıklı bir toplumun oluşmasına en büyük engeli oluşturur. ${ }^{17}$

Kayıt dışı istihdam nedeniyle işverenler vergi ve diğer mali yükümlülüklerden (örneğin, sigorta primi ödeme yükümlügünden) kurtulsalar dolayısıyla kayıt dışılık onların yararına gözükse de söz konusu istihdamın işverenler bakımından da birtakım olumsuz sonuçları bulunmaktadır. Her şeyden önce kayıt dışı ekonomi, yeraltı ekonomisinde çalışan firmalar ile kayıtlı ekonomide çalışan firmalar arasında haksız ve "yıkıcı" (ruinous) bir rekabete yol açar (Schneider, 2015, s. 3). Bu bağlamda özellikle firmalar bakımından olmak üzere prim ödeyenlerle ödemeyenler arasında haksız ve yıkıcı bir rekabete yol açılmış olunmakta, işverenler, sistemde kayıtlı olan işyerlerini, belirli bir zamandan sonra diğer işyerleri ile rekabet edebilme amacıyla kayıt dışılığa yöneltmektedir. Yine iyi niyetle sistemde olan kişiler, kayıt dışı çalışan/çalıştıran kişilerden kötü bir şekilde etkilenerek bilinç kirliliği oluşmaktadır (http://www.sgk.gov.tr, 11.04.2016).

Kayıt dışı istihdamın devlet açısından da çok önemli olumsuz sonuçları bulunmaktadır. Bu bağlamda kayıt dışı istihdam nedeniyle devlet büyük miktarda prim kaybına uğramakta, bu durum ise sosyal güvenlik açıklarını önemli ölçüde artırmaktadır. ${ }^{18}$ Devlet, sosyal güvenlik açıklarını kapatabilmek için bütçeden transfer yapmak durumunda kalmakta, bu transfer ise bütçe açıklarını artırmakta ve gelecek nesiller sosyal güvenlik sisteminden kaynaklanan yükleri taşımak zorunda kalmakta ve sistemden yeterli düzeyde yararlanamamaktadırlar. Yine kayıt dışı istihdam yüzünden bu istihdam türünde çalışanlar tatminkâr ücret alamadıkları için yeterli gelir olanaklarına kavuşamamakta böylelikle gelir dağılımındaki adaletsizliklere yol açılmış olunmaktadır. Yine kayıt dışı ekonomi toplumun ahlaksal bozulma ve çöküntüsüne neden olduğu gibi kayıt dışı istihdam da aynı sakıncaları taşımaktadır (http://www.sgk.gov.tr, 11.04.2016).

\subsection{Kayıt Dışı Ekonominin Bir Türünü Oluşturan Suç Faaliyetlerinin Ülke ve Toplumu Çökertme Noktasına Getirmesi ve Onları Ateş Çemberine Sokması}

Kayı1 dışı ekonominin üç türü bulunmaktadır. Bunlardan bir kısmı tümüyle yasa dışı bir nitelik (hırsızlık, yolsuzluk, kaçakçılık, terörizm gibi) taşımakta, bir kısmı ise yasal ekonomik faaliyetleri (tarım, sanayi, hizmetler, bilişim ve bilgi) oluşturmasına karşın kayıt dışına sapılmaktadır. Kayıt dışı ekonominin son türünü oluşturan "gri ekonomi” (grey economy) ise "yarı-yasal" (semi-legal) bir nitelik taşımaktadır. Örneğin bir işyeri, izin, ruhsat veya lisans almadan mal ve hizmet sunarsa yarı-yasal şekilde kayıt dışı ekonomi alanında çalıştığı sonucuna varılır. ${ }^{19}$

\footnotetext{
${ }^{17}$ Çocuk işçiliğinin zararları ayrı bir incelemenin konusunu oluşturacak ölçüde geniş olduğundan bu işçiliğin eğitim-öğretim bakımından vereceği zararlar hakkında kısaca üzerinde durulmasının dışında diğer zararları üzerinde durulmayacaktır. Kayıt dışı ekonomide çocuk çalışmasının en önemli zararı eğitim-öğretim bakımından doğar. Zira bu ekonomide çalışan birçok çocuk okullarını terk etmekte, bu durum ise eğitim-öğretim seviyesinin düşmesine yol açmaktadır. Eğitim-öğretim bir ülkenin gönencini sağlamada temel unsur olduğundan çalışan çocukların okullarını bırakması, o ülkenin geleceğinin çalınması anlamını taşır. Öte yandan çocukları yeterli bir eğitim almamış bir ulusun kayıt dışı ekonomisi artar ve bu durum o ulus ve toplumun ekonomik, sosyal ve kültürel yaşamının kirlenmesine yol açar. Krş. Michael P. Todaro, Economic Development, Fifth Edition, Longman, New York 1994, s. 363 vd.

${ }^{18}$ Sosyal güvenlik kurumlarının açıklarının artmasının, bir başka deyişle söz konusu kuruluşların finansman dengesini bozulmasının birtakım sosyal sonuçları bulunmaktadır. Gerçekten de sosyal güvenlik kurumlarının finansman dengesinin bozulması, bir başka deyişle kayıt dışı ekonominin prim gelirlerinin azalmasına yol açması yüzünden yoksullara sosyal transferler yapılamamakta, böylelikle düşük gelirli grupların yaşam koşulları daha da zorlaşmaktadır. Örneğin sosyal güvenliğin finansmanında en önemli gelir kalemi olan prim in yetersiz olması yüzünden mevcut emeklilerin durumları iyileştirilememektedir. Ayrıca bu durum gelir dağılımındaki bozukluğun ve sosyal adaletsizliğin daha da çok artmasına neden olmaktadır. Krş. Ulaş ve Öztürk, s. 43.

${ }^{19}$ Fazla bilgi için bkz. Friedrich Schneider, Konrad Raczkowski ve Bogdan Mróz, Shadow economy and tax evasion in the EU, Journal of Money Laundering Control, Vol. 18, Iss 1, 2015, s. 36. (http://dx.doi.org/10.1108/JMLC-09-2014-0027, Erişim Tarihi, 14.3.2015).
} 
Kayı1 dışı ekonominin bu türleri arasında en tehlikeli olanı tümüyle yasa dışı bir nitelik taşıyan suç veya yasa dış1 faaliyetlerdir. Suç faaliyetleri, teknik bir deyişle, yeraltı ekonomisi, ülke ve insanların refahını artırmak şöyle dursun, tam anlamıyla çökertici bir etki taşır. Bu bağlamda örneğin, yukarıda belirtildiği üzere çocuk ve gençlere satılan uyuşturucu maddeler, ülke ve toplum refahını adeta dinamitler.

Kayıt dış1 ekonominin bir türünü oluşturan suç faaliyetlerinin ezici çoğunluğu, örneğin sigara, uyuşturucu veya mazot kaçakçılığı terör veya mafya tipi organizasyonlar tarafından gerçekleştirilmekte ve bu organizasyonlar, siyasetçiler ve kamu görevlilerini yolsuzluğa bulaştırmadan söz konusu faaliyetlerinin etkin bir şekilde yürütülemeyeceğinin bilincine ulaşmış bulunmaktadırlar. Suç ekonomisinin bizzat kendisinin yolsuz olması ${ }^{20}$ ve yolsuzluğu artırıcı bir etki doğurması toplumsal değerleri aşındırıcı bir nitelik taşıyarak ülke ve toplumu içten içe kemirmekte, böylelikle ülke ve toplumun çöküşü için uygun bir ortam sağlamaktadır. Ayrıca terör veya mafya tipi organizasyonların sunduğu mal ve hizmetleri satın almak, söz konusu organizasyonların semirmesine ve büyümesine yol açmakta, bu durum ise ülke ve toplumu bir ateş çemberi içerisine sokmaktadir (Dursun, 2001, s. 111).

\subsection{Kayıt Dışı Ekonominin Kentlerde Yoğunlaşmasının Kent İstihdamı ve Çevresel Açılardan Sorunlara Yol Açması}

Kayıt dışı ekonominin kentlerde yoğunlaşmasının en önemli sakıncalarından birisi söz konusu ekonominin köyden kente göçü teşvik etmesidir. Köyden kente göçen insanların büyük çoğunluğu kayıt dışı olarak istihdam edilecektir. Köyden göçenler, hem kayıt dışı ekonomide işe girerken bekleme süresini kısaltmakta hem de bu ekonomideki işsizlik oranını azaltmaktadırlar. Gölge ekonomide gelir ve istihdamın teşvik edilmesi kentin işsizlik oranını artırmaktadır. Zira resmi ve kayıt dışı ekonominin özümseyeceğinden daha fazla olarak emek arzı sunulmaktadır.

Bundan da öte kayıt dışı ekonominin kentlerde yoğunlaşmasının çevre bakımından oldukça büyük olumsuz sonuçları bulunmaktadır. Gerçekten de çoğu enformel sektör faaliyetleri örneğin seyyar arabalarda yapılan satışlar gibi kirliliğe ve izdihama yol açmakta, seyyar satıcı ve ayak satıcısı, yayalara ve araba sürücülerine rahatsızlık vermektedir. Bundan da öte kayıt dışı ekonomide çalışan kesimlerin çoğunluğunun düşük gelirli ailelerin oluşturduğu varoş ve gecekondularda oturması olgusu ile söz konusu yerlerdeki kent hizmetlerinin yetersizliğinin birleşmesi kentler için devasa sorunlara yol açmaktadır (Todaro, 1994, s. 256).

\section{KAYIT DIŞI EKONOMIYE KARŞI HALKIN BÍLINÇLENDİRILMESINIIN YÖNTEMI}

Yukarıda ayrıntılı bir şekilde görüldüğü üzere kayıt dışı ekonominin inanılmaz zararları bulunmakta ve bu ekonomi; ekonomik, sosyal ve kültürel yaşamı tahrip ederek ülkeyi ve toplumu çökertme noktasına getirmekte ve ahlaki değerleri aşındırmaktadır. Ahlaki değerleri aşınmış bir toplum şimdiki halde berbat bir yaşam süreceği gibi geleceği de parlak olmayacaktır. Bu çerçevede gölge ekonominin zararları konusunda toplumun her kesiminin dikkatinin çekilmesi, böylece toplum fertlerinin bilinçaltına kayıt dışı ekonominin zararlarının kazınarak sosyal bir şuurun oluşturulması kaçınılmaz bir zorunluluktur.

Bununla birlikte Türkiye'de toplumsal düzeyde kayıt dış1lığa bakış açısı, kayıt dışılığın istihdam yarattığı ve ekonomiyi dışsal şoklara karşı koruyan bir supap olduğu biçimindeki yanılgıları içermektedir. Bu yanılgının sürdüğü bir ortamda kayıt dışı ekonomiyle başarılı bir savaşım verebilmek oldukça güçleşmektedir. Bu bakış açısının değiştirilmesi, kayıt dışı ile savaşımda başarı sağlanması bakımından büyük önem taşımaktadır (Ulaş ve Öztürk, 2006, s. 151-152).

Türk halkının kayıt dışı ekonomiye karşı bakışındaki yanılsamanın uygun yöntemlerle giderilmesi gerekmektedir. Söz konusu yanılsamanın giderilmesi bakımından Onuncu Kalkınma Planında (2014-2018) herhangi bir hükme rastlanılamamış, Dokuzuncu Kalkınma Planında ise isabetli hükümlere yer verilememiştir. Konu oldukça önemli olduğundan üzerinde biraz daha durulması yerinde olacaktır.

\footnotetext{
${ }^{20}$ Kayıt dişı ekonominin diğer türlerini oluşturan yasal ve yarı-yasal ekonomik faaliyetler ise yolsuzluk için uygun bir ortam sağlamakta, bir başka deyişle, yolsuzluk ile kayıt dışı ekonominin diğer türleri arasında pozitif bir "korelasyon" (ilgileşim) bulunmaktadır. Bu durum, kayıt dışı ekonominin kamu kesiminin büyüklüğ̈nü ve etkinliğini sınırlandıracağını örtük bir şekilde ortaya koymaktadır. Konu hakkında ayrıntılı bilgi için bkz. Francisco Azpitarte, Can Corruption constrain the size of governments?, European J Law Econ, 32, 2011, s. 1-14.
} 
Dokuzuncu Kalkınma Planının (2007-2013) “7.1.3. Ekonomide Kayıtdışılığın Azaltılması” Kısmında, insanların kayıtlı ekonomi içerisinde yer almalarını özendirecek ve kayıt dışı ekonominin zararlarını anlatacak bilgilendirme kampanyalarının düzenleneceği, broşürler dağıtılacağı ve eğitimlerin verileceği ifade edilmektedir (Dokuzuncu Kalkınma Planı(20072013),2006:75). Dokuzuncu Kalkınma Planının ekonomide kayıt dışılığı azaltmak için öngördüğü bu sosyal bilinç yöntemini benimsemek olanaksızdır. Bir kere kayıt dışı ekonomiye karşı broşür dağıtılmasının ülkede bir karşılığı bulunmamaktadır. Gerçekten de Türkiye'de her şeyden önce okuma alışkanlığı yok denecek kadar az bir seviyede bulunmaktadır. Bu bağlamda AB ülkelerinde \%21 olarak gerçekleşen kitap okuma oranının, Türkiye'de yalnızca \%0,01 olarak gerçekleştiğini belirtmek gerekir. Daha açık bir deyişle, Türkiye'de günde ortalama altı-buçuk saat televizyona, ${ }^{21}$ üç saat İnternete ayrılırken, kitap okumaya yılda sadece altı saat ayrılmıştır. UNESCO'nun dünyadaki okuma alışkanlıkları raporuna göre Türkiye, kitap okuma oranında dünya ülkeleri arasında 86. sırada; Gambiya, Fildişi Cumhuriyeti gibi Afrika ülkeleriyle birlikte yer almıştır. Üstelik Türkiye'de on binde bir kişinin okuduğu kitaplara baktığımızda bunların eğitici ve kültürü artırıcı olmaktan ziyade genellikle fikra kitapları, dini içerikli yayınlar ve aşk romanları başı çekmiştir. ${ }^{22}$ Bu bağlamda Dokuzuncu Kalkınma Planında kayıt dışı ekonomiyi azaltmak için öne sürülen broşürler dağıtılması düşüncesi isabetli değildir. Zira bu tip bir faaliyete karşı halk herhangi bir ilgi göstermeyecek ve böylelikle kayıt dışı ekonomiye karşı halkın bilinçlenmesi sağlanamayacaktır.

Yukarıda yapılan açıklamalardan anlaşılacağı üzere kayıt dışı ekonomiye karşı Türk halkını bilinçlendirilmesinin en etkili yolu televizyondur. Bu çerçevede kayıt dışı ekonominin bahsedilen zararlarının anlatıldığı kısa metrajlı filmlerin çekilmesi uygun olacaktır. Bu filmlerde sıradan yurttaş oynayacak ${ }^{23}$ ve daha sonra bir uzman, kayıt dışı ekonominin kötülüğüne vurgu yaparak halkta o ekonominin kötülüğü konusunda bir bilinç uyandıracaktır. Örneğin seyyar bir satıcı kalabalık ortamda bir yurttaşı mal alması için rahatsız edecek, daha sonra konunun uzmanı ekranda görünerek "seyyar satıcının yayalara rahatsızlık verdiğini, bu rahatsızlığın oluşmaması için seyyar satıcıdan mal alınmaması, kayıt dışı ekonomiye geçit verilmemesi gerektiğini” vurgulayacaktır.

Kayıt dışı ekonominin kötülükleri konusunda kısa metrajlı filmler çekilirken yalnızca kayıt dışı yasal ekonomik faaliyetler türü değil, yasa dışı ekonomik faaliyetler türü bakımından da halkta bilinç uyandırılması gerekmektedir. Örneğin, torbacı olarak adlandırılan kaçak bir sigara satıcısı, ucuz olduğu gerekçesiyle vatandaşı kaçak sigara almaya ikna edecek, vatandaş tam sigarayı alırken sigaranın üzerine $X$ işareti konulacaktır. Daha sonra uzman bir kişinin görüntüsü gelerek "kaçak sigara alımının sağlı̆̆a inanılmaz derecede korkunç zararlar verdiğini, sigara kaçakçılığının tek başına gerçekleştirilemeyeceğini, bu tip faaliyetlerin çıkar amaçlı suç organizasyonları veya terör örgütleri tarafından gerçekleştirildiğini, yurttaşın kaçak sigara almasının, terör veya mafya tipi örgütlerin devasa bir şekilde büyümesine ve semirmesine yol açtı̆̆ını, terör örgütlerinin veya organize suç gruplarının toplumun başına bela olduğunu ve onların asalak olduğunu, toplumun kanını emdiklerini, yurttaşlar kaçak sigara almaya devam ederlerse toplumun hızla çürüyerek çökeceğini” belirtecektir.

\footnotetext{
${ }^{21}$ TÜIKK tarafindan geçmişte yapılan bir araştırmada televizyon izlenme oranları bakımından Türkiye'nin dünya ikincisi olduğu ortaya konulmuştur. Gerçekten de bu araştırmaya göre Amerika'da günde ortalama olarak 5 saat televizyon seyredilirken, Türkiye 4,5 saatle hemen bu ülkenin arkasında yer almıştır. Erkan Gukrer, Televizyon izlemede dünya ikincisiyiz (http://www.pclaps.com.tr/2010/05/07televizyon-izlemede-dunya-ikincisiyiz/print/, Erişim Tarihi, 02.10.2012). Günümüzde ise Türkiye günlük 6,5 saat televizyon izleme oranı ile dünya rekoru kırmışıtır. Gerçekten de Ajans Press'in medyada gerçekleştirdiği araştırmaya göre günlük televizyon izleme oranları Türkiye'de 330 dakika, hemen arkasından gelen Japonya'da ise 265 dakika olarak gerçekleşmiştir. Bu araştırmada dikkat çeken husus, daha önceleri televizyon seyretme oranı bakımından dünya birincisi olan Amerika Birleşik Devletlerinin yeni araştırmada ilk 10 ülke arasında bile isminin geçmemesidir. Cumhuriyet Gazetesinin 3 Nisan 2017 tarihli Türkiye, televizyon izleme süresinde dünya rekoru kırdı başlıklı haberine bkz. (www.cumhuriyet.com.tr, Erişim Tarihi, 19.1.2018).

${ }^{22}$ Bkz. AB ülkelerinde yüzde 21 olan kitap okuma oranı, Türkiye'de sadece yüzde 0,01, 1 Ocak 2015 tarihli AB Haber (http://www.abhaber.com/abulkelerinde-yuzde-21-olan-kitap-okuma-orani-turkiyede-sade... Erişim Tarihi, 22.04.2016).

${ }^{23}$ Kayıt dışı ekonominin zararlarının anlatıldığı kısa metrajı bu filmler çekilirken sıradan yurttaşlar ile konunun uzmanlarına rol verilmeli, hiçbir şekilde sanatçı veya siyasilere yer verilmemesi gerekir. Bunun iki nedeni bulunmaktadır. Bunlardan ilki, bir sanatçı veya siyasetçinin toplumun tüm kesimleri tarafından sevilmesi olanaksız olduğundan onun vereceği mesajın toplumdaki sevilmeyen kesimler üzerinde herhangi bir olumlu etkisinin olmaması, bir başka deyişle, sanatçı veya siyasilerin toplumun belirli kesimleri tarafından sevilmemesi yüzünden onların vereceği mesajın bütünleştirici ve kapsayıcı olmaktan uzak kalabilmesidir. Hatta bu kişilerin vereceği mesajın olumsuz bir tesir doğurması da olanaklıdır. Bu durumda kayıt dışı ekonominin azaltılacağı yerde daha da fazlalaşmasına! yol açılmış olunacaktır. İkinci neden sanatçılar bakımından olmak üzere maliyet kaygılarıdır. Filmlerin çekimi yapılırken kamu kaynağı kullanılacağından mümkün olduğu kadar tasarrufa gidilmesi gerekir. Bu çerçevede sanatçıların filmlerde rol almaması gerekir. Zira filmde oynamak için birçok sanatçı yüksekbedel talep edeceğinden bu durum filmlerin maliyetini artıracak ve böylelikle kamu kaynağının israf edilmesi olgusuyla karşılaşılacaktır.
} 
Kayıt dışı ekonominin ülke ve topluma verdiği çok sayıda korkunç zararların her biri için bu tip filmler çekilirken uzman kişinin görüntüsünden sonra ekranda görünmeyen bir kişinin fon sesi verilmeli, bu seste ise kayıt dışı ekonomi ile mücadele konusunda Gelir İdaresi Başkanlığı bünyesinde “Alo Kayıt D1şı Ekonomiyle Mücadele Hattı"24 kurulduğu belirtilerek bu hatta yapılacak ihbarlarda ihbarcıların isim veya kimlik bilgilerini vermelerinin şart olmadığı vurgulanarak, kayıt dış1 ekonominin halk tarafından bildirilmesi çağrısı yapılmalıdır. Çekilen bu filmlerin, RTÜK ile irtibata geçilerek bütün televizyonlarda "kamu spotu" şeklinde yayımlanması sağlanmalıdır.

Kayıt dışı ekonominin kötülüklerinin anlatıldığı kısa metrajlı filmlerin halkta bu ekonomiye karşı tam bir tiksinti uyandırabilmesi için bir yıl boyunca televizyonlarda yayımlanması uygun olacaktır. Daha somut bir deyişle, Gelir İdaresi Başkanlığının senaryosunu hazırladığı kayıt dışı ekonomiden doğan zararların anlatıldığı kısa metrajlı filmler TRT tarafından çekilmeli, çekilen filmler RTÜK'e teslim edilerek, RTÜK'ün talimatıyla bütün televizyonlarda "kamu spotu” olarak bir yıl boyunca oynatılması gerekir. Bir yıl boyunca kayıt dışı ekonominin kötülüğünün anlatıldığı filmlerin televizyonlarda yayımlanması, söz konusu ekonomiye karşı halkta derin bir bilinç oluşturma bakımından önemli bir kilometre taşı oluşturacaktır.

\section{SONUÇ}

Yukarıda belirtildiği üzere günümüzde 28 AB üyesi ülkenin kayıt dışı ekonomisinin GSMH'ye oranının ağırlıksız ortalaması yaklaşık \%18 seviyesinde, Türkiye'de ise yaklaşık \%28 civarında bulunmaktadır. Aslında kayıt dışı ekonominin boyutunu tam olarak hesaplamak mümkün değildir. Bu çerçevede hangi yöntem (örneğin nakit para talebi gibi) uygulanırsa uygulansın bu ekonominin hacminin tam olarak hesaplanması olanaksızdır. Öte yandan, kayıt dışı ekonominin bir türünü oluşturan suç faaliyetlerinin örneğin eroin satışının doğası gereği gizli olması bu ekonominin boyutunun hesaplanmasını daha da güçleştirmektedir. ${ }^{25}$

Kayıt dışı ekonominin boyutlarının tam olarak hesaplanmasının imkânsız olması olgusu ile Schnedir'in hesaplamalarına göre günümüzde bu ekonominin GSMH'ye oranının \%28 gibi nispeten düşük bir oran oluşturmasından, Türkiye'de gölge ekonominin pek fazla sorun oluşturmadığı veya yüksek miktarda olmadığı sonucu çıkartılmamalıdır. Günlük yaşamda da kolaylıkla fark edileceği üzere Türkiye'de kayıt dışı ekonomi çok yüksek boyutlarda gözükmekte ve bu bağlamda onun GSMH'den daha aşağı olduğu yönündeki tahminler inandırıcı gözükmemektedir. Tersine bir deyişle, Türkiye'de kayıt dışı ekonominin GSMH veya onun üzerinde olduğu yönündeki tahminler daha doğru gözükmektedir.

Türkiye'de kayıt dışı ekonominin bu boyutlarda yüksek olması katlanılabilir bir durum değildir. Bu ekonominin AB ortalamasının daha aşağısında, mutlak surette tek haneli rakamlara indirilmesi bir zorunluluktur. Kayıt dişı ekonominin tek haneli rakamlara indirilmesi sonucuna ancak bu ekonominin kötülükleri konusunda halkın bir bilince sahip olması sayesinde ulaşılabilir. Kuşkusuz kayıt dışı ekonomiye karşı salt halkın bilincinin oluşturulması yöntemiyle mücadele verilemez. Bu ekonomiye karşı etkili bir savaşım verilebilmesi için örneğin kayıt içi ekonomik faaliyetlerin özendirilmesi gibi başka önlemlerin de alınması gerekir. Ancak kayıt dışı ekonomiye karşı toplumsal bilinç oluşturulması dışında hangi yöntemler kullanılırsa kullanılsın bu ekonominin katlanılabilir bir seviyeye getirilmesi olanaksızdır. Hatta o yöntemlerle kayıt dışı ekonominin $\mathrm{AB}$ ortalaması olan \%18 seviyesine çekilebilmesi de olanaklı olabilir. Ancak söz konusu AB ortalaması bile sürdürülebilir ve katlanılabilir olmaktan hayli uzaktır. Bu ekonomi yalnızca tek haneli rakamlara düşürülerek katlanılabilir bir seviye getirilir ki söz konusu düşük rakamlara diğer yöntemlerle birlikte kayıt dışı ekonomiye karşı halkta bir bilincin oluşturulması yöntemiyle ulaşılabilir. Zira insanlık, günümüze kadar, sorunların çözülmesinde o soruna karşı toplum bilincinin oluşturulması dışında daha etkili bir yöntemi bulamamıştır.

Kayıt dışı ekonomiye karşı toplumun bilinçlendirilmesi, bu ekonomiye karşı kısa, orta ve uzun vadeli ve kalıcı olarak ölümcül darbe vuracaktır. Nitekim 1980'li yıllarda İsviçre'de kayıt dışı ekonominin GSMH'nin \%3 ila \%5'I (Case E.ve Fair

\footnotetext{
${ }^{24}$ Kayıt dışı ekonomiye karşı oluşan toplumsal bilincin pratik bir işleve sahip olması için Gelir İdaresi Başkanlığı bünyesinde "Kayıt Dışı Ekonomi ile Mücadele Grubu” ile “Alo Kayıt Dışı Ekonomiyle Mücadele Hattı” kurulması gerekir. Bu hatta iletilen kayıt dışı ekonomi ile ihbarlar söz konusu grup tarafından suç oluşturuyorsa genel kolluk gücünü oluşturan Emniyet Genel Müdürlüğü, Jandarma Genel Komutanlığı veya Sahil Güvenlik Komutanlığına, istihdam kaçağı oluşturuyorsa Sosyal Güvenlik Kurumu Başkanlığına, vergi kayıplarına yol açıyorsa kendi iç birimlerine bildirilmesi gerekir. Böylelikle sonul hedef olan kayıt dışı ekonomiye ölümcül bir darbe vurulması ereğine ulaşılmış yönünde önemli bir adım atılmış olunacaktır.

${ }^{25}$ Nitekim Schneider, Raczkowski ve Mróz (s. 34) haklı olarak, MIMIC istatistiklerinin kayıt dışı ekonominin büyük kısmını oluşturan suç faaliyetlerini kapsamayacağını ve bu çerçevede söz konusu istatistiklerin tüm kayıt dışı ekonominin mutlak boyutunu vermeyeceğini belirtmektedirler.
} 
C., 1989, s. 555) günümüzde ise $\% 6$ ila $\% 7$ arasında $^{26}$ küçük bir miktarı oluşturmasının altında yatan temel etmen, kanımızca, halkın, bu ekonominin geleceklerini çalacağı yönünde sahip olduğu derin bilinçtir. Halkın kayıt dışı ekonomiye karşı bir bilincinin oluşmadığı durumlarda bu ekonominin yol açtığı kötülüklerle baş edebilmek olanaksız değilse bile oldukça güçtür. Bu bağlamda kayıt dışı ekonomi sorununun çözümünde halkın bilinçlenmesinin en etkili bir yöntem olduğu tartışma götürmez bir gerçekliktir.

Aslında kayıt dışı ekonomiye karşı verilecek savaşımda en etkili silahın söz konusu ekonominin kötülükleri konusunda halkta bir bilinç oluşturulması olduğu evrensel olarak kabul edilmiş bir gerçekliktir. Ancak bu gerçeği uygularken kayıt diş1 ekonomiye karşı bir ülkenin kullandığı aracın başka bir ülkede işe yaramayabileceğini gözden uzak tutmamak gerekir. Örneğin Türkiye'de 1 kişinin okumaya ayırdığı zamanın; bir Norveçli 300, Amerikalı 210, İngiliz ve Japon 87 katını ayırdığından ${ }^{27}$ söz konusu ülkelerde kayıt dışı ekonomiye karşı yazılı basın yoluyla yapılan bilgilendirme kampanyaları Türkiye'de işe yaramayacaktır. Yukarıda ayrıntılı bir şekilde gösterildiği üzere televizyon seyretmeye düşkünlük bakımından dünyanın ilk sıradaki ülkesi olarak yer alan Türkiye açısından kayıt dışı ekonomiye karşı bilinç yalnızca televizyon yoluyla halkın bilinçaltına nüfuz edilerek gerçekleştirilebilecektir. Bu bağlamda kayıt dışı ekonominin kötülükleri bakımından halkta bilinç oluşturulması için görsel basının kullanılması dışında etkin bir yolun bulunmadığı açık bir gerçekliktir. ${ }^{28}$ Zira ekonomik gelişme ile birlikte kayıt dışı ekonominin kendiliğinden azalacağı beklentisi boşa çıkmış, hatta tam tersine artmıştır. Bunun için kayıt dışı ekonomiyle mücadele için aktif politikalara ve bu meyanda halkta bilinç oluşturmaya önem verilmesi gereği ortaya çıkmıştır.

Aslında kayıt dışı ekonominin zararları konusunda halkta bir bilinç oluşturulması bir tavsiye değil adeta bir zorunluluk olarak kendisini hissettirmektedir. Zira yukarıda belirtildiği üzere halkta kayıt dışı ekonominin istihdam yarattığı ve dışsal şoklara karşı koruyan bir supap olduğu şeklinde bir yanılgı bulunmaktır.

Çeşitli defalar belirtildiği üzere halkın kayıt dışı ekonomiye karşı bilinçlendirilmesi bakımından Türkiye açısından en etkili yöntemi söz konusu ekonominin kötülüklerinin anlatıldığı kısa metrajlı "kamu spotu" şeklinde filmler oluşturacaktır. Televizyon seyretmeye aşırı düşkün olan Türk halkının algısı bu filmler sayesinde değişecek ve halk kayıt dışı ekonomiyi amansız bir düşman olarak görerek ${ }^{29}$ yeterli bilinç seviyesine ulaşacaktır. Kayıt dışı ekonominin zararları bakımından 7'den 77'ye kadar herkeste bir bilinç oluştuğu durumda halkın söz konusu ekonomiye verdiği destek azalacak, kayıt dış1 ekonomik faaliyetlerin yoğunluğu düşerken kayıt içi ekonomi güçlendirilmiş olunacaktır.

Halkın kayıt dışı ekonomiye karşı bilinçlendirilmesi söz konusu ekonomiyi kısa, orta ve uzun dönemde kalıcı olarak azaltmak ve katlanılabilir bir seviyeye getirmek bakımından yaşamsal bir önem taşımaktadır. Zira kayıt dışı ekonominin düşük ve katlanılabilir bir seviyeye getirilmesi ancak halkın desteği sağlanarak başarılabilir, halkın desteği de yalnızca halkta söz konusu ekonominin kötülükleri konusunda bir bilinç oluşturulması yoluyla elde edilebilir.

Kayıt dışı ekonominin tek haneli rakamlara indirilerek kalıcı olarak azaltılamadığı bir durumda ülkenin ve toplumun geleceği çalınmış olacaktır. Bu çerçevede yoğun ve yaygın bir şekilde bulunan kayıt dışı ekonomi Türkiye'yi ekonomik, sosyal, kültürel ve ahlaki yönlerden sürekli erozyona uğratacak ve AB'ye tam üye olma hedefi ham bir hayal olmaktan öteye geçemeyecektir.

\footnotetext{
${ }^{26}$ İsviçre'de kayıt dışı ekonominin İsviçre GSMH'sına oranı 2013 yılında \%7,1, 2014 yılında \%6,9, 2015 yılında ise \%6,5 olarak gerçekleşmiştir. Bkz. Schneider, Size and Development of the Shadow Economy of 31 European and 5 other OECD Countries from 2003 to 2015: Different Developments, s. 7.

${ }^{27}$ Bkz. Bunları biliyor musunuz?, Özet Kitap, 2013 (http://www.ozetkitap.com/tr/bunlari-biliyor-musunuz, Erişim Tarihi, 22.4.216).

${ }^{28}$ Nitekim Türkiye'de yazılı materyali okuma oranı oldukça düşüktür. Kitap, Türkiye'de ihtiyaç maddeleri siralamasında 235. sirada bulunmakta, Türk çocukları kitap okuma konusunda çoğu Afrika ülkelerinin gerisinde kalmış durumdadır. Japonya'da toplumun \%14'ü, ABD'de \%12'si, İngiltere ve Fransa'da \%21'i düzenli kitap okurken, Türkiye'de yalnızca 1/10.000 kişi düzenli olarak kitap okumaktadır. Sekiz milyon nüfuslu Azerbaycan'da kitaplar ortalama 100 bin baskıyla basılırken, 78 milyonluk Türkiye'de bu rakam ortalama 2-3 bin arasında değişmektedir. Zira Türkiye'de okuma alışkanlığına sahip kişilerin sayısı 70 bin civarında bulunmaktadır. BM araştırmasına göre kitap için yılda Norveçli 137, Alman 122, Belçikalı ve Avusturyalı 100, Güney Koreli $39 \$$ ayırırken, Türk 0,45\$ harcamaktadır. Dünya ortalaması 1,3\$ civarındadır. Türkiye'de kütüphane sayıs 1412, kahvehane sayıs1 570.000'dir. Buna göre yaklaşık 55.000 kişiye bir kütüphane düşerken 140 kişiye bir kahvehane düşmektedir. BM'nin insani gelişmişlik raporunda kitap okuma oranına göre ülkelerin sıralamasında Türkiye; Malezya, Libya ve Nijerya gibi ülkelerin bulunduğu 173 ülke arasında 86. sırada yer almaktadır. Bkz. Bunları biliyor musunuz?, Özet Kitap, 2013.

${ }^{29}$ Zira kayıt dışı ekonominin kötülük ve zararlarının anlatıldığı kısa metrajlı filmlerde filmlerin konusu halkın bilinçaltına işleyerek bu ekonominin kötülükleri konusunda halkta derin bir bilinç oluşturulacaktır.
} 
Bu çalışmada son olarak önemli bir hususa temas etmek uygun olacaktır. Kayıt dışı ekonomiyle savaşımda en büyük rol hukukçulara düşmektedir. Zira ülkemizde kayıt dışı ekonomi yaygın bir şekilde yer aldığı için ekonomik ve sosyal düzeni korumak amacıyla çıkartılmış bulunan İş Kanunu, sosyal güvenlik kanunları ve Türk Tícaret Kanunu gibi temel kanunlar uygulanmayarak devre dişı kalmakta ve bu durum ekonomik ve sosyal yaşamda önemli ölçüde kargaşa ve karışıklığa yol açmaktadır. Ayrıca kayıt dışı sektörlerde çalışan kimseler, aşırı ölçüde çalıştırılarak, izin hakkı verilmeyerek, yıpratıcı ve yorucu işler yaptırtılarak ve diğer yollarla ağır insan hakları ihlallerine maruz kalmaktadırlar. Bu çerçevede kayıt dışı ekonomi ile mücadele eden bir hukukçunun, ekonomik ve sosyal yaşamda düzeni sağlamaya katkı ve insan haklarıyla etkin bir mücadele vermek bakımından kayıt dışı ekonomiyle mücadele etmeyen bir hukukçuya göre görevini daha iyi bir şekilde yerine getirdiği ortadadır.

\section{KAYNAKÇA}

Azpitarte, F. (2011). Can Corruption constrain the size of governments?, European J Law Econ, 32.

Bowden, V. Elbert (1996). Economics The Science of Common Sense, South-Western Publishing Co., Ohio.

Case, E. Karl \& Fair, C. R. (1989). Principles of Economics, Principles of Economics, Prentice Hall, New Jersey.

Çetintaş, Hakan \& Vergil, H. (2003). Türkiye'de Kayıtdışı Ekonominin Tahmini, Doğuş Üniversitesi Dergisi, 4 (1), $15-30$.

Dokuzuncu Kalkınma Planı (2007-2013).(2006). Devlet Planlama Teşkilatı, Ankara.

Dursun, H. (2001).Organize Suça Genel Bir Bakış, Devlet Planlama Teşkilatı Yayınları, Ankara.

Dursun, H. (2009). Nasıl Bir Yargı Reformu, Adalet Yayınevi, Ankara.

Gregory, R. Paul \& Roy, J. R. (1989). Basic Macroeconomics, Scott, Foresman and Company, USA.

Gukrer, Erkan, Televizyon izlemede dünya ikincisiyiz (http://www.pclaps.com.tr/2010 /05/07televizyon-izlemede-dunya-ikincisiyiz, Erișim Tarihi, 02.10.2012).

Ilgın Y. (1999). Kayıtdışı Ekonomi ve Türkiye'deki Boyutları, DPT-Uzmanlık Tezleri, DPT Yayınları, Ankara.

Ilgın, Y. (2002). Kayıtdışı Ekonomiyi Tahmin Yöntemleri ve Türkiye'de Durum, Planlama Dergisi, DPT’nin Kuruluşunun 42. Yılı Özel Sayı, Ankara.

Onuncu Kalkınma Planı (2014-2018). (2013). Kalkınma Bakanlığı, Ankara.

Onuncu Kalkınma Planı (2014-2018). (2015). Kayıtdışı Ekonominin Azaltılması Programı Eylem Planı, Koordinatör Gelir İdaresi Başkanlı̆̆ı, Kalkınma Bakanlığı, Ankara.

Sarıkaya, H. E. (2007). Kayıt Dışı Ekonomi’nin Ekonomik Büyümeye Etkisi: Türkiye Örneği (1980-2005) (Yüksek Lisans Tezi, Selçuk Üniversitesi, Sosyal Bilimler Enstitüsü, Konya). (https://tez.yok.gov.tr/UlusalTezMerkezi/tezDetay.jsp?id=Y0f-hQCvtSZiiyyjOmIghw\&no= ebRiDeUW6IcFrxZJraKbcw, Erişim Tarihi, 10.05.2021)

Sekizinci Beş Yıllık Kalkınma Planı. (2001). Kayıtdışı Ekonomi Özel İhtisas Komisyonu Raporu, Ankara.

Schiller, R. B. (1991). The Macro Economy Today, Fifth Edition, McGraw-Hill, USA.

Schneider, Friedrich, Shadow Economy in Turkey and in other OECD-Countries: What do we (not) know?, http://www.gep.gov.tr/tmp/BSEC\%20pdf/Prof.\%20Dr.\%20Friedrich\%20Schneider\%20ShadEc_Turkey2012.pdf, Erişim Tarihi, 15.3.2016).

Schneider, Friedrich, Size and Development of the Shadow Economy of 31 European and 5 other OECD Countries from 2003 to 2015 : Different Developments (Bkz. http: //www.econ.jku.at/members/Schneider/files/publications/2015/ShadEcEurope31.pdf, Erişim Tarihi, 15.3.2016).

Schneider, Friedrich, Konrad Raczkowski ve Bogdan Mróz, Shadow economy and tax evasion in the EU, Journal of Money Laundering Control, Vol. 18, Iss 1, 2015 (http://dx.doi.org/10.1108/JMLC-09-2014-0027, Erişim Tarihi, 14.1.2015).

Siggel, E. (2010). The Indian informal sector: The impact of globalization and reform, International Labour Review, Vol. 149 , No.1.

Sugözü, H. İ. (2010). Kayıt Dışı Ekonomiyi Önlemede Vergi Politikaları (1980-2004 Türkiye Örneği), SÜ İIBF Sosyal ve Ekonomik Araştırmalar Dergisi, Cilt 10, Sayı 19, 171-192.

Todaro, P. M. (1994). Economic Development, Fifth Edition, Longman, New York.

Ülgen, S. \& Öztürk, U. (2006). Kayıtdışı Ekonomi ve Sürdürülebilir Büyüme, TÜSİAD, İstanbul. 
